УДК 338.4: 664

DOI: $10.15673 /$ fie.v10i4.1135

\author{
Шалений В.А. \\ старший викладач \\ кафредра управління бізнесом \\ Одеська національна академія харчових технологій \\ вул. Канатна, 112, Одеса, Україна, 65039 \\ E-mail: shalenyy@i.ua
}

\title{
КІЛЬКІСНИЙ АНАЛІЗ РІВНЯ РИЗИКОВАНОСТІ ДІЯЛЬНОСТІ ПІДПРИЕМСТВ: КЛЮЧОВІ ПОКАЗНИКИ
}

У статті розглядаються основні теоретико-методичні аспекти оцінки рівня ризикованості діяльності підприємств. Кількісна оцінка ризиків в цілому передбачає розв'язання двох завдань: вибір методу оцінки ризиків та визначення міри та ступеня ризику у вигляді показника, або групи показників. Велика кількість показників, яка використовується в практиці управління ризиками, вимагає їх систематизації, що і було проведено автором.

Вибір кількісних показників, які доцільно застосовувати в кожній конкретній ситуації, залежить від певних чинників, серед яких ключовими $є$ наявність інформації щодо кількісних характеристик ризику, виду ризику, обмеження ресурсів, в тому числі часу, вимог щодо повноти вихідної інформації для прийняття управлінських рішень.

Ключові слова: ризик, оцінка ризиків, управління ризиками, відносні та абсолютні показники, статистичні показники, систематизація.

This work is licensed under a Creative Commons Attribution 4.0 International License http://creativecommons.org/licenses/by/4.0/

Постановка проблеми та її зв'язок із важливими науковими та практичними завданнями. Ефективне функціонування підприємств в умовах динамічного ринкового середовища, агресивності їх зовнішнього оточення, значної конфліктності інтересів стейкхолдерів вимагає побудови комплексної системи управління ризиками. Обов'язковою умовою при цьому є отримання всебічної та достовірної інформації щодо кількісних параметрів реальних та потенційних ризиків. Такі параметри мають в кінцевому підсумку формалізуватися у системі відповідних кількісних показників. Практика ризик-менеджменту свідчить, що ефективність управлінських рішень знаходиться у прямій залежності від кількості використаних при аналізі ризиків показників за умови достовірності їх значень та дотримання принципів системності та комплексності (сукупність показників має комплексно характеризувати дію ризиків на підприємство як складну поліструктурну систему, з великою кількістю взаємозв’ язаних та взаємозалежних елементів).

Аналіз останніх публікацій по проблемі. Основні теоретичні аспекти визначення сутності ризиків як економічної категорії, їх оцінки та управління розглядаються у фундаментальних роботах А. Сміта [1], Ф.Х. Найта [2], Й. Шумпетера [3]. Серед сучасних зарубіжних науковців, що займаються аналізом ризиків у підприємництві, можна відзначити Е. Холмса [4], А.П. Альгіна [5], І.Т. Балабанова [6]. Дослідження ризику як важливого атрибуту ринкової економіки знайшли відображення у роботах таких вітчизняних економістів, як І.Ю. Івченко [7], В.В. Вітлінського [8], В.М. Гранатурова [9], В.В. Лук'янової [10] та інших.

Слід однак зауважити, що більшість досліджень не приділяють достатньої уваги необхідності побудови системи кількісних показників оцінки ризиків, узгодженої з відповідними класифікаційними ознаками та сутнісними характеристиками цих ризиків.

Отже, на сьогоднішній день виключну актуальність має дослідження можливості застосування для комплексної оцінки ризиків системи показників, узгодженої з сутнісними характеристиками ризиків. Сукупність таких показників має дати всебічну та вичерпну кількісну характеристику ідентифікованим ризикам, що є необхідною умовою розробки та проведення заходів, спрямованих на мінімізацію таких ризиків.

Формулювання цілей дослідження. Метою дослідження $є$ аналіз теоретико-методичних підходів до кількісної оцінки ризиків підприємств в розрізі ключових показників та їх систематизація.

Виклад основних результатів та їх обгрунтування. Кількісний аналіз рівня ризикованості діяльності підприємств є одним 3 ключових етапів ризик-менеджменту та виконується часто навіть у випадках, якщо на підприємствах відсутній ризикменеджмент як окремий вид діяльності або функція управління 3 відповідними задачами та ресурсами. Незважаючи на те, що в таких випадках управління ризиками $\epsilon$ фрагментарним та несистемним, кількісна 
оцінка ризиків з наступною його обробкою все одно дозволяє значно знизити негативний вплив ризиків.

Процедура проведення кількісної оцінки ризиків в загальному вигляді передбачає розв'язання наступних завдань:

вибір методу оцінки окремого ризику або групи ризиків, який найкращим чином відповідатиме вихідній інформації, наявним ресурсам, вимогам щодо кінцевих результатів оцінки та іншим умовам і обмеженням;

- визначення міри та ступеня ризику у вигляді показника, або групи показників.

Аналіз літературних джерел щодо методів, які використовуються при кількісній оцінці ризиків, дозволяє зробити висновок, що велика кількість 3 них $\epsilon$ лише способом обробки відповідної інформації (даних), тобто певними алгоритмами та процедурами проведення розрахунків, а тому виключно важливим $\epsilon$ визначення теоретичних та практичних аспектів розрахунку та використання відповідних кількісних показників, які б комплексно характеризували ступінь та міру ризику.

Перш за все слід відзначити, що ризик вимірюється двома кількісними характеристиками: ймовірністю реалізації загроз та появи на підприємстві негативних наслідків, а також розміром втрат (збитків, додаткових витрат тощо), насамперед, матеріальним, які є результатом реалізації зазначених загроз.

Доцільність застосування тих чи інших показників визначається різновидом ризиків, які підлягають оцінці.

В загальному вигляді кількісний аналіз ризиків може проводиться за:

- статистичними показниками, які використовуються при загальному аналізі економічних явищ і процесів;

специфічними показниками, які використовуються лише в практиці управління ризиками.

До першої групи показників кількісної оцінки ризиків доцільно віднести наступні.

Очікуване значення (середнє очікуване значення) [11]. Показник очікуваного значення EV (expected value) являє собою агрегування інформації відносно ймовірності та матеріального результату реалізації ризику у вигляді прямих втрат, або іншого показника, який характеризує такий результат (прибуток, обсяг продажів, витрати тощо).

$$
E V=\mathrm{H}_{\mathrm{i}} * \mathrm{p}_{\mathrm{i}},
$$

де $\mathrm{H}_{\mathrm{i}}$ - матеріальний результат реалізації ризику,

$\mathrm{p}_{\mathrm{i}}$ - ймовірність реалізації ризику.

В теорії ризиків цей показник також має назву EMV (expected monetary value).

Розмах варіаціï або розмах коливань (Rvar) показує діапазон усіх можливих значень матеріального результату реалізації ризику [11], та може використовуватись для характеристики можливості виникнення нетипових ситуацій, які $є$ наслідком реалізації сукупності ризикоутворюючих чинників. Показник також характеризує ступінь невизначеності стану та перспектив розвитку підприємства як складної системи та загальний рівень професіоналізму його менеджменту. Розмах варіації розраховується наступним чином:

$$
\text { Rvar }=\mathrm{H}_{\max }-\mathrm{H}_{m i n}
$$

де $\mathrm{H}_{\max }$ та $\mathrm{H}_{\min }$ - відповідно найбільше та найменше значення матеріального результату, які можуть бути отримані в результаті реалізації ризику.

Незважаючи на простоту та наочність показника, він має і значні недоліки, серед яких головним вважається його недостатня інформативність щодо характеристики варіації $\mathrm{H}_{\mathrm{i}}$, тобто він не дає можливості якісно описати досліджуваний процес.

Цієї негативної ознаки позбавлений інший статистичний показник, який на нашу думку, також може бути використаний для загальної оцінки рівня ризикованості діяльності.

Середнє лінійне відхилення (dr) [11] також, як i попередній показник в цілому характеризує рівень невизначеності розвитку досліджуваного явища або процесу та описує рівень ризикованість діяльності в таких одиницях виміру, як і сам показник ризику $\mathrm{H}_{\mathrm{i}}$, але на відміну від попереднього враховує усі значення результату реалізації ризику як випадкової величини, а тому $є$ більш інформативним.

Середнє лінійне відхилення розраховується за формулою:

$$
d_{r}=\frac{\sum_{i=1}^{n}\left|H_{i}-H_{\text {cepp }}\right|}{n}
$$

де $\mathrm{n}$ - кількість варіантів реалізації ризику.

Використання при оцінці рівня ризикованості діяльності показника середнього лінійного відхилення пов'язане 3 незручностями, насамперед 3 тим, що виникає необхідність проводити обробку не тільки позитивних, але і від'ємних значень $\mathrm{H}_{\mathrm{i}}$, що спонукало дослідників шукати інші способи оцінки варіації та рівня ризикованості діяльності. Таким способом стало зведення всіх відхилень в другу ступінь. Узагальнюючі показники, знайдені 3 використанням других ступенів відхилень, отримали дуже широке поширення. До таких показників відносяться середнє відхилення і середнє квадратичне відхилення в квадраті, яке називають дисперсією. Ці показники вважаються одними 3 ключових при оцінці варіації досліджуваних рядів даних та, відповідно, вони $з$ успіхом використовуються при оцінці невизначеності та ризикованості діяльності.

Дисперсія розраховується по формулах (4) та (5) для процесів та явищ 3 різною та однаковою ймовірністю реалізації випадкових подій відповідно [9]:

$$
\begin{aligned}
& \delta^{2}=\sum_{i=1}^{n}\left(H_{i}-H_{c e p}\right)^{2} * p_{t} \\
& \delta^{2}=\frac{\sum_{i=1}^{n}\left(\mathrm{H}_{i}-\mathrm{H}_{c e p}\right)^{2}}{n-1}
\end{aligned}
$$

Середнє квадратичне відхилення визначається за формулою:

$$
\delta=\sqrt{\delta^{2}}
$$


Усі наведені вище статистичні показники є абсолютними вимірниками ризику, тобто характеризують його в таких одиницям виміру, що й $\mathrm{H}_{\mathrm{i}}$.

В практиці управління ризиками більш інформативними, та відповідно, важливішими відносно перелічених вище показників, вважаються відносні показники ризикованості діяльності.

Відносні показники характеризують рівень ризику, виражений в абсолютному виразі, віднесений до певної основи або бази.

Серед статистичних відносних показників оцінки варіації, які можуть використовуватись для кількісної оцінки ризику, на нашу думку доцільно виділити такі, як коефіцієнт осциляції (Косц), лінійний коефіцієнт варіації (Kvar $\left.{ }_{\text {lin }}\right)$ та коефіцієнт варіації (Kvar), які виражаються, як правило, у відсотках [11].

Коефіųiєнт осцилляиї є відносним показником розмаху варіації та розраховується за формулою:

$$
\text { Косц }=\frac{R_{\text {var }}}{H_{\text {sap }}}(\%)
$$

Лінійний коефіųiєнт варіації в свою чергу є відносним показником середнього лінійного відхилення та розраховується за формулою:

$$
\text { IV } \operatorname{var}_{\operatorname{lin}}-\frac{d_{r}}{\mathrm{H}_{\mathrm{cep}}}(\%)
$$

Коефіuієнт варіаціï розраховується за наступною формулою:

$$
\mathrm{Kvar}=\frac{\delta}{\mathrm{H}_{\mathrm{egp}}}(\%)
$$

Коефіцієнт варіації є відносною мірою ризику, оскільки абсолютне значення середнього квадратичного відхилення нормується на значення очікуваного результату реалізації ризику. При позитивному математичному очікуванні, чим нижче коефіцієнт варіації, тим менше розкид показника щодо його очікуваного значення.

Коефіцієнт варіації за думкою багатьох науковців серед усіх наведених вище показників дає найбільш комплексну оцінку варіації (в даному випадку ступеню ризикованості діяльності). Слід відмітити, що за допомогою коефіцієнта варіації можна порівнювати коливання ознак, виражених у різних одиницях виміру.

Коефіцієнт варіації дає можливість визначити загальний рівень невизначеності та ризикованості діяльності.

Так, Лук'янова В.В. [10] виходячи з величини коефіцієнта варіації пропонує використовувати наступну шкалу рівня невизначеності та ризикованості діяльності:

- менше $10 \%$ мінімальний ризик;

- від $10 \%$ до $25 \%$ малий ризик;

- від 25\% до 50\% допустимий ризик;

- від 50\% до 75\% критичний ризик;

- більше 75\% катастрофічний ризик.

До недоліків коефіцієнту варіації з точки зору інформації про ризик, яку він надає, варто віднести те, що він враховує як позитивні, так і негативні від- хилення $\mathrm{H}_{\mathrm{i}}$, а отже його використання при оцінці спекулятивних ризиків в цілому не $є$ доречним. Для оцінки таких ризиків (дій, або подій, реалізація яких може призвести як до негативних, так і до позитивних наслідків для підприємства) доцільним є використання коефіцієнту семіваріації (коефіцієнту напівваріаціiі), розрахунок якого здійснюється таким же чином, як і розрахунок коефіцієнту варіації, однак лише за негативними значеннями.

Про привабливість цього коефіцієнту з точки зору простої та зрозумілої інтерпретації його значення наголошував ще Марковіц, однак навіть він через складність розрахунку коефіцієнту семіваріації в кінцевому підсумку від нього в своїх працях відмовився.

Другу групу показників, які доцільно визначати та аналізувати при оцінці рівня ризикованості операційної діяльності, як зазначалося вище, складають специфічні показники, котрі використовуються виключно в практиці управління ризиками.

Як і попередню групу показників, їх можна розділити на дві групи: абсолютні та відносні.

До найбільш популярних кількісних показників першої групи відносять:

1. Value at Risk (VaR) - вартісна міра ризику [12]. Показник представляє собою виражену в грошових одиницях оцінку величини, яку не перевищать очікувані протягом даного періоду часу втрати з заданою вірогідністю.

VaR характеризується трьома параметрами:

- Часовий горизонт, який залежить від ситуації, що розглядається.

- Довірчий рівень (confidence level) - рівень допустимого ризику. В практиці управління ризиками найчастіше використовується рівень допустимого ризику на рівні 95\% (рідше 99\%).

- Базова валюта, в якій вимірюється показник.

Економічний зміст показника $\mathrm{VaR}$ полягає в оцінці величини матеріальних втрат, яка $з$ ймовірністю, що дорівнює рівню довіри, не буде перевищена.

\section{2. Умовний $\mathrm{VaR}(\mathrm{cVaR})$}

Одним з подальших напрямків розвитку методики оцінки ризиків $є \mathrm{cVaR}$ - Conditional VaR або Expected Shorfall (ES) (іноді також Average value at risk (AVaR) або Expected tail loss (ETL)), що представляє собою середній очікуваний розмір матеріальних втрат, за умови, що він перевищить відповідне значення VaR [12].

На відміну від VaR, даний показник дозволяє не тільки виділити нерегулярний ризик, а й визначити, що, швидше за все, відбудеться при його реалізації.

3. Earnings at Risk (EaR), є за своїм змістом протилежним по відношенню до VaR. Показник EaR характеризує максимальний позитивний ефект, який може принести ризикова ситуація протягом певного періоду часу із заданою довірчою ймовірністю [12].

Слід зазначити, що при оцінці чистих ризиків, економічний зміст даного показника в цілому втрачається, однак його значення може бути використане для оцінки профілю ризику. 
4. EaR / | VaR | [12]. Чим вище значення зазначеного показника, тим більш привабливою $\epsilon$ господарська ситуація або відповідний проект, 3 точки зору діючих на нею (нього) ризиків. Для симетрично розподілених випадкових величин, які характеризують ситуацію ризику та можливі його наслідки, зазначений показник наближатиметься до одиниці. Таким чином, його значення може бути використане для оцінки асиметрії профілю ризику.

Слід зазначити, що усі перелічені вище специфічні абсолютні показники рівня ризику використовуються сьогодні, насамперед, при оцінці фінансових ризиків, однак з огляду на порядок їх розрахунку та економічний зміст, вони з успіхом можуть застосовуватись при оцінці майже будь-яких ризиків.

Серед відносних показників ризикованості діяльності в практиці оцінки та управління ризиками найбільшого поширення набув такий показник, як коефіцієнт ризику.

Більшість авторів під цим показником розуміють величину можливих збитків (видатків, витрат), віднесених до деякої бази:

$$
\text { Krisk }=\frac{\mathrm{H}}{\mathrm{K}}
$$

де $\mathrm{H}$ - матеріальний результат реалізації ризику або сукупності ризиків (абсолютна величина ризику);

K - база у вигляді ресурсів, капіталу, витрат або доходів (частини доходів), яка використовується для порівняння 3 можливими наслідками реалізації ризиків.

3 огляду на розглянуті вище абсолютні показники оцінки рівня ризикованості діяльності, в якості чисельника коефіцієнту ризику, тобто матеріального результату реалізації ризику, доцільно використовувати: зику EV;

- очікуване значення втрат від реалізації ри-

- показник VAR;

- показник cVAR;

- максимальне значення втрат від реалізації ризиків $\left(\mathrm{V}_{\max }\right)$.

Ризики, які виникають на підприємствах в процесі їх діяльності, відповідно до частоти потенційної реалізації можна розділяти на дві групи: регулярні та нерегулярні. Регулярні ризики є результатом реалізації випадкові процесів, які в цілому є збалансованими та однорідними. Нерегулярний ризик $\epsilon$ результатом сумісної однонаправленої негативної дії типових для даного виду діяльності чинників або результатом дії нетипового ризику.

Перші два показники (EV та VAR) доцільно використовувати для оцінки впливу на підприємство регулярних ризиків, що визначає очікуваний або нормальний для підприємства в сучасному стані рівень ризику.

Останні два показники (cVAR та $\mathrm{V}_{\max }$ ) доцільно використовувати для оцінки можливості реалізації загрозливих, критичних та катастрофічних ризиків як конкретного втілення нерегулярних ризиків.

В якості знаменника коефіцієнту ризику, на нашу думку, можуть бути використані наступні абсолютні показники:

- чистий прибуток;

- прибуток від операційної діяльності;

- чистий дохід від реалізації продукції, товарів, робіт, послуг;

- власний капітал;

- капітал (активи).

В таблиці 1 наведені коефіцієнт ризику при використанні різних матеріальних результатів реалізації ризиків (чисельник) та баз (знаменник).

Таблиця 1

Розрахунок коефіцієнту ризику діяльності підприємств та характеристика типу ризику

і оцінки його рівня*

\begin{tabular}{|c|c|c|c|c|}
\hline База $\begin{array}{l}\text { חорівняння } \\
\text { періліальний результат } \\
\text { реалізаї ризиків }\end{array}$ & EV & VAR & cVAR & $\mathrm{V}_{\max }$ \\
\hline Чистий прибуток & \multicolumn{2}{|c|}{ Регулярний мінімальний } & \multicolumn{2}{|c|}{ Нерегулярний мінімальний } \\
\hline Прибуток від операційної діяльності & \multicolumn{2}{|c|}{$\begin{array}{c}\text { Регулярний } \\
\text { прийнятний та середній }\end{array}$} & \multicolumn{2}{|c|}{$\begin{array}{c}\text { Нерегулярний } \\
\text { прийнятний та середній }\end{array}$} \\
\hline $\begin{array}{l}\text { Чистий дохід від реалізації продукції, } \\
\text { товарів, робіт, послуг }\end{array}$ & \multicolumn{2}{|c|}{$\begin{array}{l}\text { Регулярний } \\
\text { загрозливий }\end{array}$} & \multicolumn{2}{|c|}{$\begin{array}{c}\text { Нерегулярний } \\
\text { загрозливий }\end{array}$} \\
\hline Власний капітал & \multicolumn{2}{|c|}{ Регулярний критичний } & \multicolumn{2}{|c|}{ Нерегулярний критичний } \\
\hline Капітал (активи) & \multicolumn{2}{|c|}{ Регулярний катастрофічний } & \multicolumn{2}{|c|}{ Нерегулярний катастрофічний } \\
\hline
\end{tabular}

* розроблено автором

Розрахунок кожного 3 наведених в таблиці варіантів показника дає можливість визначити наявність або оцінити загрозу реалізації тих чи інших ризиків.

Абсолютне значення показника характеризує присутній або відсутній на підприємстві даний вид ризику (регулярний/нерегулярний) на визначеному рівні (очевидно, що характеристики більш загрозли- вих видів ризику поглинають менш загрозливі).

Можливість та доцільність застосування тих чи інших показників великою мірою визначається методами дослідження кількісного впливу ризиків на результати діяльності підприємств. В таблиці 2 наведені основні характеристики найбільш поширених в практиці управління ризиками методів та відповідні їм показники. 


\section{Таблиця 2}

Основні методи та показники кількісної оцінки ризиків підприсмств*

\begin{tabular}{|c|c|c|}
\hline $\begin{array}{c}\text { Метод } \\
\text { (група методів) }\end{array}$ & Показники оцінки & $\begin{array}{c}\text { Ключові характеристики та особливості використання } \\
\text { при кількісній оцінці ризиків }\end{array}$ \\
\hline $\begin{array}{l}\text { Експертні } \\
\text { (мозковий штурм, } \\
\text { Делфі, контрольні } \\
\quad \text { листи тощо) }\end{array}$ & $\begin{array}{c}\text { Ранги або рейтинг (в залежно- } \\
\text { сті від конкретного методу та } \\
\text { цілей оцінки) }\end{array}$ & $\begin{array}{l}\text { Застосуються як допоміжні або у випадках відсутності } \\
\text { достатньої інформації для використання інших методів } \\
\text { (розрахунково-аналітичних, статистичних та ймовірні- } \\
\text { сних). В цілому характеризуються низькою достовір- } \\
\text { ністю результатів оцінки }\end{array}$ \\
\hline $\begin{array}{l}\text { Аналіз сценаріїв, } \\
\text { дерево рішень }\end{array}$ & EV & $\begin{array}{l}\text { Ефективні при оцінці ризиків, які як випадкові проце- } \\
\text { си характеризують дискретний простір станів об'єкта } \\
\text { ризику, а кожний стан може бути охарактеризований } \\
\text { ймовірністю його настання та матеріальним результа- } \\
\text { том, який є наслідком цього стану. Методи є простими } \\
\text { у застосуванні, часто використовується графічна візуа- } \\
\text { лізація досліджуваної проблеми. }\end{array}$ \\
\hline $\begin{array}{c}\text { Статистичні та ймо- } \\
\text { вірнісні }\end{array}$ & $\begin{array}{l}\text { Статистичні абсолютні та від- } \\
\text { носні показники, а також спе- } \\
\text { цифічні показники оцінки ри- } \\
\text { зику, описані в статті }\end{array}$ & $\begin{array}{l}\text { Вимагають значного масиву достовірної інформації } \\
\text { щодо кількісних ознак об'єкта ризику. Достатньо ви- } \\
\text { сока достовірність результатів оцінки. Є одними } \\
\text { найпоширеніших методів кількісної оцінки ризиків. }\end{array}$ \\
\hline Теорії ігор & $\begin{array}{c}\text { Критерії Лапласа, Вальда, Се- } \\
\text { віджа, Гурвіца, МАХІМАХ) }\end{array}$ & $\begin{array}{l}\text { Вимагають інформації щодо кількісних ознак об’єкта } \\
\text { ризику: ймовірностей відповідних станів та очікуваних } \\
\text { матеріальних результатів. Показники (критерії) є, пе- } \\
\text { редусім, не кількісною характеристикою ризику, а } \\
\text { основою прийняття управлінських рішень. }\end{array}$ \\
\hline $\begin{array}{l}\text { Доцільності } \\
\text { витрат }\end{array}$ & $\begin{array}{c}\text { Порівняння ефекту від впро- } \\
\text { вадження заходів з витратами } \\
\text { на них }\end{array}$ & $\begin{array}{l}\text { Використовуються, головним чином, при оцінці ефек- } \\
\text { тивності заходів, спрямованих на управління (мінімі- } \\
\text { зацію) ризиків. Метод є розрахунково-аналітичним, а } \\
\text { тому забезпечує високу достовірність результатів оці- } \\
\text { нки. }\end{array}$ \\
\hline Аналіз чутливості & $\begin{array}{l}\text { Коефіцієнт еластичності (ха- } \\
\text { рактеризує відносну зміну } \\
\text { інтегрального показника при } \\
\text { заданій (наприклад } 1 \% \text {-вій) } \\
\text { зміні ризик-змінної }\end{array}$ & $\begin{array}{l}\text { Простий метод визначення ключових зон ризику, пе- } \\
\text { редусім, проектних. Метод забезпечує високу достові- } \\
\text { рність результатів оцінки. }\end{array}$ \\
\hline $\begin{array}{l}\text { Імітаційне } \\
\text { моделювання } \\
\text { Монте-Карло }\end{array}$ & $\begin{array}{l}\text { Статистичні абсолютні та від- } \\
\text { носні показники, а також спе- } \\
\text { цифічні показники оцінки ри- } \\
\text { зику, описані в статті }\end{array}$ & $\begin{array}{l}\text { Ефективність методу значною мірою залежить від кі- } \\
\text { лькості прогонів моделі, а отже можливостей обчис- } \\
\text { лювальної техніки. Передумови застосування методу } \\
\text { аналогічні до статистичних та ймовірнісних, але ре- } \\
\text { зультати розрахунків дають можливості прийняття } \\
\text { управлінських рішень на якісно новому рівні (виділен- } \\
\text { ня різних типів ризиків, дослідження можливих відка- } \\
\text { зів системи тощо). Перспективним є сумісне викорис- } \\
\text { тання методу з апаратом нечіткої логіки. }\end{array}$ \\
\hline $\begin{array}{c}\text { Точка } \\
\text { беззбитковості }\end{array}$ & $\begin{array}{c}\text { Точка беззбитковості (поріг } \\
\text { рентабельності), запас міцнос- } \\
\text { ті, коефіцієнт безпеки }\end{array}$ & $\begin{array}{l}\text { Метод застосовується при дослідженні ризиків опера- } \\
\text { ційної діяльності, є простим, в цілому не вимагає гли- } \\
\text { бокого ретроспективного аналізу об'єкта ризику та } \\
\text { дозволяє отримати достовірні дані щодо загальної ри- } \\
\text { зикованості операційної діяльності підприємства. }\end{array}$ \\
\hline R-аналіз & $\begin{array}{l}\text { Фінансові коефіцієнти (показ- } \\
\text { ники фінансової стійкості, } \\
\text { рентабельності, майнового } \\
\text { стану, ділової активності, лік- } \\
\text { відності та платоспроможнос- } \\
\text { ті) } \\
\end{array}$ & $\begin{array}{l}\text { Використовується широке коло показників, що дає } \\
\text { можливість отримання комплексної оцінки рівня ризи- } \\
\text { кованості діяльності об'єкта. } \\
\text { Розрахунки проводяться на основі даних фінансової та } \\
\text { статистичної звітності об'єкта, що забезпечує високий } \\
\text { рівень достовірності кінцевих оцінок ризику. }\end{array}$ \\
\hline $\begin{array}{l}\text { Моделі оцінки за- } \\
\text { грози банкрутства } \\
\text { (моделі Альтмана, } \\
\text { Бівера, Ліса, Арген- } \\
\text { ті тощо) }\end{array}$ & $\begin{array}{l}\text { Z-рахунок Альтмана (трьох, } \\
\text { п’яти- та семифакторна моде- } \\
\text { лі), коефіцієнт Бівера, Z- } \\
\text { рахунок Ліса, А-score Аргенті }\end{array}$ & $\begin{array}{l}\text { На основі розрахунку групи фінансових показників } \\
\text { визначається ймовірність (потенційна загроза) банк- } \\
\text { рутства об'єкта оцінки протягом визначеного терміну. } \\
\text { В умовах вітчизняної економіки та правового поля } \\
\text { моделі та відповідні показники не демонструють дос- } \\
\text { товірності отриманих оцінок та вимагають значної } \\
\text { адаптації. }\end{array}$ \\
\hline
\end{tabular}

*Узагальнено автором за аналізом джерел [6,8,10,11,12,13,14] 
Значний вплив на вибір показників як інструментарію оцінки діючих на підприємство ризиків робить потенційний результат реалізації цих ризиків: чисті та спекулятивні ризики в більшості випадків вимагають використання якісно різних показників.

Висновки та перспективи подальших досліджень. Підвищення ефективності управлінських рішень щодо мінімізації реальних та потенційних ризиків потребує максимально достовірної та повної інформації щодо кількісних параметрів цих ризиків, що вимагає використання сукупності різних за своїм економічним змістом показників. Використання значної кількості цих показників в практичних цілях потребує відповідної їх систематизації та визначення кола ризиків, які можуть бути максимально вичерпно описані цими показниками.

Вибір кількісних показників, які доцільно застосовувати в кожній конкретній ситуації, залежить від певних чинників, серед яких ключовими є вибір методу оцінки, наявність інформації щодо кількісних характеристик ризику, виду ризику, обмеження ресу- рсів, в тому числі часу, вимог щодо повноти вихідної інформації для прийняття управлінських рішень.

Серед усіх показників оцінки ризиків з точки зору комплексності даних, які отримуються на виході кількісної оцінки ризиків, особливої уваги заслуговує коефіцієнт ризику: багатоваріантність способів його розрахунку надає можливості менеджменту підприємства врахувати максимально широке коло можливих ризиків та загроз, оцінити необхідність формування відповідних резервів, розробити інші заходи, спрямовані на мінімізацію ризиків.

3 урахуванням результатів аналізу кількісних показників оцінки ризику, перспективним напрямком подальших досліджень є розробка системи кількісних показників ризиків у прив'язці до відповідних його видів 3 урахуванням пріоритетності: чим вищим $\epsilon$ пріоритет ризику (важливість для підприємства, що визначається на етапі якісного аналізу ризиків), тим більш системною та комплексною має бути його оцінка, що в свою чергу пов'язане 3 необхідністю використанням відповідною кількості достовірних показників.

\section{Література}

1. Смит, А. Исследование о природе и причинах богатства народов: Кн.1-3 / Смит А.; пер. с англ. Абалкин Л.И. Москва: Наука, 1993. 570 с.

2. Найт Ф.Х. Риск, неопределенность и прибыль / Найт Ф.Х.; пер. с англ. Каждана М.Я. Москва: Дело, 2003. $360 \mathrm{c}$.

3. Шумпетер Й. Теорія економічного розвитку. Дослідження прибутків, капіталу, кредиту, відсотка та економічного циклу / Шумпетер Й.; пер. 3 англ. В. Старка. Київ: Видавничий дім «Києво-Могилянська академія», 2011. 242 с.

4. Холмс Э. Риск-менеджмент / Холмс Э.; пер. с англ. В. Хмелевская. Москва: Изд-во Эксмо, 2007. 304 c.

5. Альгин А.П. Грани экономического риска: учебник. Москва: Знание, 1994. 264 с.

6. Балабанов И.Т. Риск-менеджмент: учебник. Москва: Финансы и статистика, 1996. 192 с.

7. Івченко І.Ю. Економічні ризики: підручник. Київ: Центр навчальноі літератури, 2004. 304 с.

8. Вітлінський В.В., Наконечний С.І., Шарапов О.Д. Економічний ризик і методи його вимірювання: підручник. Київ: ІЗМН, 1996. 400 с.

9. Гранатуров В.М. Экономический риск: сущность, методы измерения, пути снижения: підручник. Москва: Дело и сервис, 2002. 160 с.

10. Лук'янова В.В., Головач Т.В. Економічний ризик: навчальний посібник. Київ: Академвидав, 2007. 464 c.

11. Маховикова Г.А., Касьяненко Т.Г. Анализ и оценка рисков в бизнесе: учебник и практикум для академического бакалавриата. Москва: Юрайт, 2014. 464 с.

12. Holton, Glyn A. Value-at-Risk: Theory and Practice, second edition. 2014. URL: http://value-at-risk.net (дата звернення: 25.10.2018).

13. ДСТУ IEC/ISO 31010:2013 (IEC/ISO 31010:2009,IDT). Національний стандарт України. Керування ризиком. Методи загального оцінювання ризику. URL: http://metrology.com.ua/download/iso-iec-ohsas-i-dr/87eea/1062-dstu-ies-iso-31010-2013 (дата звернення: 25.10.2018).

14. Петрович Й.М., Прокопишин-Рашкевич Л.М. Економіка і фінанси підприємства: підручник. Львів: Магнолія, 2014. 406 с. 


\author{
Шаленый В.А. \\ старший преподаватель \\ кафедра управления бизнесом \\ Одесская национальная академия пищевых технологий \\ Ул. Канатная, 112, г.Одесса, Украина, 65039 \\ E-mail: shalenyy@i.ua
}

\title{
КОЛИЧЕСТВЕННЫЙ АНАЛИЗ УРОВНЯ РИСКА ДЕЯТЕЛЬНОСТИ ПРЕДПРИЯТИЙ: КЛЮЧЕВЫЕ ПОКАЗАТЕЛИ
}

\begin{abstract}
В статье рассматриваются основные теоретико-методические аспекты оценки уровня риска деятельности предприятий.

Количественный анализ рисков опирается на два их свойства: вероятность реализации угроз и появления на предприятии негативных последствий, а также размеры потерь, полученных в результате реализации указанных угроз. Оценка рисков в целом предполагает решение двух задач: выбор метода оценки отдельного риска или группы рисков, который наилучшим образом будет отвечать исходной информации, имеющимся ресурсам, требованиям конечных результатов оценки и другим условиям и ограничениям, а также определения меры и степени риска в виде показателя, или группы показателей.
\end{abstract}

Анализ литературных источников по методам, которые используются при количественной оценке рисков, позволяет сделать вывод, что основном они являются лишь способом обработки соответствующей информации, то есть по сути алгоритмами проведения расчетов, а поэтому с точки зрения необходимости получения количественных параметров действующих рисков исключительно важным является определение ключевых показателей, которые бы комплексно характеризовали меру и степень риска. Наличие большого количества показателей, используемых в практике управления рисками, требует их систематизации, что и было проведено в работе.

В общем виде количественный анализ рисков может проводится по статистическим показателям, которые используются при общем анализе экономических явлений и процессов и специфическим показателям, которые используются только в практике управления рисками.

Выбор количественных показателей, которые целесообразно применять в каждой конкретной ситуации, зависит от определенных факторов, среди которых ключевыми являются наличие информации о количественных характеристик риска, вида риска, ограничения ресурсов, в том числе времени, требований относительно полноты информации для принятия управленческих решений.

Ключевые слова: риск, оценка рисков, управление рисками, относительные и абсолютные показатели, статистические показатели, систематизация.

\author{
Shaleny V. \\ Assistant \\ Department of Management of Business \\ Odessa National Academy of Food Technologies \\ Kanatna str., 112, Odesa, Ukraine, 65039 \\ E-mail: shalenyy@i.ua
}

\section{QUANTITATIVE ANALYSIS OF THE RISK LEVEL OF BUSINESS ACTIVITIES OF ENTERPRISES: KEY INDICATORS}

The article considers the main theoretical and methodological aspects of assessing the level of riskiness of enterprises.

Quantitative risk analysis is based on two of their characteristics: the likelihood of the implementation of threats and the appearance of negative consequences on the enterprise, as well as the size of losses, which is the result of the implementation of these threats. The risk assessment as a whole involves the solution of two tasks: the choice of the method for assessing a particular risk or a group of risks that best suits the source information, available resources, requirements for the end results of the assessment and other conditions and constraints, and the determination of the measure and degree of risk in the form of an indicator, or groups of indicators.

The analysis of literary sources about the methods used in quantitative risk assessment suggests that a large number of them are only a way of processing the relevant information, that is, in essence, the algorithms for calculations, and therefore, from the point of view of the need to obtain quantitative parame- 
ters of the existing risks is extremely important is the definition of key indicators that would characterize the degree and degree of risk in a complex way.

The large number of indicators used in risk management practice requires systematization, which was carried out by the author.

In general, quantitative risk analysis can be carried out according to statistical indicators used in the general analysis of economic phenomena and processes and specific indicators used only in the practice of risk management.

The choice of quantitative indicators that should be applied in each particular situation depends on certain factors, among which the key is the availability of information on quantitative risk characteristics, the type of risk, resource constraints, including time, requirements for the completeness of the source information for making managerial decisions.

Keywords: risk, risk assessment, risk management, relative and absolute indicators, statistical indicators, systematization.

\section{References}

1. Smit, A. (1993). Issledovanie o prirode i pričinah bogatstva narodov (Vol. 1-3) (L. I. Abalkin, Trans.). Moskva: Nauka.

2. Nayt, F. H. (2003). Risk, neopredelennost'i pribyl'(M. Ya. Kazhdana, Trans.). Moskva: Delo.

3. Shumpeter, Y. (2011). Teorîa ekonomičnogo rozvitku. Doslidžennâ pributkìv, kapitalu, kreditu, vidsotka ta ekonomičnogo ciklu (V. Stark, Trans.). Kyiv: Vidavničij dìm «Kiêvo-Mogilâns'ka akademìa».

4. Holms, E. (2007). Risk-menedžment (V. Hmelevskaya, Trans.). Moskva: Èksmo.

5. Algin, A. P. (1994). Grani èkonomičeskogo riska. Moskva: Znanie.

6. Balabanov, I. T. (1996). Risk-menedžment. Moskva: Finansy i statistika.

7. Ivchenko, I. Yu. (2004). Ekonomični riziki. Kyiv: Centr navčal'noi literaturi.

8. Vitlinskyi, V. V., Nakonechnyi, S. I., \& Sharapov, O. D. (1996). Ekonomičnij rizik i metodi jogo vimìûvannâ. Kyiv: IZMN.

9. Granaturov, V. M. (2002). Èkonomičeskij risk: Suŝnost', metody izmereniâ, puti sniženiâ. Moskva: Delo i servis.

10. Luk'ianova, V. V., \& Holovach, T. V. (2007). Ekonomičnij rizik. Kyiv: Akademvidav.

11. Mahovikova, G. A., \& Kasyanenko, T. G. (2014). Analiz i ocenka riskov v biznese. Moskva: Ûrajt.

12. Holton, G. A. (2014). Value-at-Risk: Theory and Practice. Retrieved November 25, 2018, from http://value-at-risk.net

13. DSTU İES/ÌSO 31010:2013 (ÌES/İSO 31010:2009,IDT). Nacìonal'nij standart Ukraïni. Keruvannâ rizi-

kom. Metodi zagal'nogo ocìnûvannâ riziku. Retrieved November 25, 2018, from http://metrology.com.ua/download/iso-iec-ohsas-i-dr/87-eea/1062-dstu-ies-iso-31010-2013

14. Petrovych, Y. M., \& Prokopyshyn-Rashkevych, L. M. (2014). Ekonomika i finansi pidpriêmstva. Lvìv: Magnoliâ.

Received 31 October 2018

Approved 14 November 2018

Available in Internet 29.12.2018

Цитування згідно ДСТУ 8302:2015

Шалений В.А. Кількісний аналіз рівня ризикованості діяльності підприємств: ключові показники // Економіка харчової промисловості. 2018. Т.10, вип. 4. С. 79-86. doi: 10.15673/fie.v10i4.1135

Cite as APA style citation

Shaleny V. (2018). Quantitative analysis of the risk level of business activities of enterprises: key indicators. Food Industry Economics, 10(4), 79-86; doi: 10.15673/fie.v10i4.1135 